\title{
Management of Biostimulant and Silicon in Mineral Nutrition and Quality of Cotton Fiber
}

\author{
William H. Fichhof ${ }^{1}$, Ricardo de A. Silva ${ }^{2}$, Luan S. de Oliveira ${ }^{3}$ \& Rudieli M. da Silva ${ }^{3}$ \\ ${ }^{1}$ Faculdade Arnaldo Horácio Ferreira, Luis Eduardo Magalhães, BA, Brazil \\ ${ }^{2}$ Plant and Animal Production Department, Universidade Estadual do Sudoeste da Bahia, Vitória da Conquista, \\ BA, Brazil \\ ${ }^{3}$ Department of Agriculture, Universidade Estadual Paulista Júlio de Mesquita Filho, Botucatu, Brazil \\ Correspondence: Ricardo de Andrade Silva, Plant and Animal Production Department, Universidade Estadual do \\ Sudoeste da Bahia, Vitória da Conquista, BA, Brazil. Tel: 55-77-9-9974-8891. E-mail: \\ ricardo_deandrade@yahoo.com.br
}

Received: June 21, 2018

doi:10.5539/jas.v10n10p476

\author{
Accepted: July 28, $2018 \quad$ Online Published: September 15, 2018 \\ URL: https://doi.org/10.5539/jas.v10n10p476
}

\begin{abstract}
Silicon ( $\mathrm{Si}$ ) and biostimulant management have been proposed techniques to reduce the impacts of abiotic stresses and to increase the productivity of several crops, however, there are still few concise results of the management of this crop. The objective of this work was to evaluate the effects of biostimulant and silicon treatments on isolated or mixed applications on mineral nutrition, yield and fiber quality of two cotton varieties. For this, an experiment was carried out in a randomized block design in the municipality of Luís Eduardo Magalhães-BA, in a $4 \times 2$ factorial arrangement, with four replications, in which four biostimulant treatments (control, without application; Si; biostimulant; and $\mathrm{Si}+$ biostimulant) were evaluated in two cotton varieties (FM 954GLT and FM 983GLT). The nutrient content of leaves, relative water content, electrolyte leakage, fiber yield, and quality were evaluated, the data collected were submitted to the F test and means were compared by Tukey at $5 \%$ probability. At the end of the experiment, it was verified that the management of Si and biostimulants increase the integrity of the cell wall, the association of $\mathrm{Si}+$ biostimulant increases the levels of $\mathrm{N}, \mathrm{Fe}$ and $\mathrm{Si}$ foliar and reduces the levels of B and $\mathrm{Mn}$, and do not influence on yield and fiber quality.
\end{abstract}

Keywords: Gossypium hirsutum L., yield, fiber quality

\section{Introduction}

The cotton crop is considered the most important natural fiber source produced in Brazil and Bahia is one of the main producing states. In the 2016/17 crop year, the area cultivated with cotton in the state was 201.6 thousand hectares, with an average yield of $4293 \mathrm{~kg} \mathrm{ha}^{-1}$, while in the 2015/16 crop year, in a planted area of 235.2 thousand hectares the average productivity was $2629 \mathrm{~kg} \mathrm{ha}^{-1}$ due to long drought periods (CONAB, 2017), representing a yield $63 \%$ lower than the 2016/17 harvest.

Several management techniques are adopted in the cotton production system, among them the application of silicon $(\mathrm{Si})$ and the use of biostimulants has enabled a reduction of the biotic stresses in the plant, which in turn result in alterations in the development and growth of the plant and fiber, and plume quality. According to Luyckx et al. (2017), silicon acts reducing the effects of water stress and directly influences fiber growth, chiefly in the maintenance of stretching and fineness.

According to Zhu and Gong (2014), the effects of Si application in cotton plants consist of the formation of a double layer of silica under the leaf epidermis, which reduces water loss through cuticular transpiration and promotes root system elongation (Hattori et al., 2005), factors that may improve the plant's ability to absorb nutrients from the soil. However, cotton is a Si-accumulating plant by specific channels (Reynolds et al., 2016) and it is essential to understand the effects of this element on the distribution of nutrients inside the plant, as well as its influence on fiber development and quality.

In relation to biostimulants, there is a vast literature that reports the effects of these products on the elevation of water stress tolerance by increasing the root system (Srivastava et al., 2016), maintaining the integrity of cell 
membranes (Soares et al., 2017), and by increasing nutrient assimilation and cotton fiber quality (Silva et al., 2016).

However, there are no reports on the effects of biostimulants with $\mathrm{CaT}^{\mathrm{TM}}$ technology on this crop. The $\mathrm{CaT}^{\mathrm{TM}}$ technology is a synthetic molecule that aims to stimulate the mobility and distribution of calcium in cell membranes and increase its concentration in the cytoplasm (Veritas $\left.{ }^{\mathrm{TM}}, 2017\right)$. The increment of cytosolic calcium for prolonged periods is one of the main mechanisms used by plants to induce tolerance to abiotic stresses, such as water and saline (Daszkowska-Golec \& Szarejko, 2013).

Thus, the purpose of this study was to evaluate the effects of biostimulant and silicon treatments in isolated and/or in mixed applications on mineral nutrition, yield and fiber quality of two cotton varieties.

\section{Method}

The experiment was conducted in the research field of the Boiadeiro farm, located at $12^{\circ} 05^{\prime} 16.99^{\prime \prime} \mathrm{S}$ and $45^{\circ} 55^{\prime} 01.70^{\prime \prime} \mathrm{W}$, in the municipality of Luís Eduardo Magalhães-BA. The climate in this region is classified as Aw (tropical climate with dry winter season), with an average temperature of $26.2{ }^{\circ} \mathrm{C}$, rainfall of $1511 \mathrm{~mm}$ during the period of experimental conduction, and 810 meters of altitude.

The soil was classified as an Endoplinthic Ferralsol according to the WRB soil classification. The soil chemical characteristics in the $0-20 \mathrm{~cm}$ layer of the experimental area are: $\mathrm{pH}$ in $\mathrm{CaCl}_{2} 6.2 ; 3.6 \%$ of organic matter; 54.51 $\mathrm{mg} \mathrm{dm}$ of P (Mehlich $\left.{ }^{-1}\right) ; 0.62 \mathrm{mmol}_{\mathrm{c}} \mathrm{dm}^{-3}$ of K; $11.98 \mathrm{mmol}_{\mathrm{c}} \mathrm{dm}^{-3}$ of Mg; $55.56 \mathrm{mmol}_{\mathrm{c}} \mathrm{dm}^{-3}$ of Ca; $0.0 \mathrm{mmol}_{\mathrm{c}}$ $\mathrm{dm}^{-3}$ of Al; $1.96 \mathrm{mg} \mathrm{dm}^{-3}$ of S; $0.51 \mathrm{mg} \mathrm{dm}^{-3}$ of B; $0.25 \mathrm{mg} \mathrm{dm}^{-3}$ of $\mathrm{Cu} ; 11.20 \mathrm{mg} \mathrm{dm}^{-3}$ of Fe; $0.15 \mathrm{mg} \mathrm{dm}^{-3} \mathrm{of}^{-3}$ $\mathrm{Mn} ; 0.43 \mathrm{mg} \mathrm{dm}$ of $\mathrm{Zn} ; 77.16 \mathrm{mmol}_{\mathrm{c}} \mathrm{dm}^{-3}$ of Cation Exchange Capacity (CEC). The soil presents sandy texture with 112,39 and $849 \mathrm{~g} \mathrm{~kg}^{-1}$ of clay, silt, and sand, respectively.

The basal fertilization consisted of $55 \mathrm{~kg} \mathrm{ha}^{-1}$ of $\mathrm{N}$ and $250 \mathrm{~kg} \mathrm{ha}^{-1}$ of $\mathrm{P}_{2} \mathrm{O}_{5}$ provided by the application of mono-ammonium phosphate (MAP) at the time of sowing (09/12/2016), and the topdressing fertilization consisted of $400 \mathrm{~kg} \mathrm{ha}^{-1}$ of KCl, corresponding to $240 \mathrm{~kg} \mathrm{ha}^{-1}$ of $\mathrm{K}_{2} \mathrm{O}$, applied at 25 days after emergence (DAE), $200 \mathrm{~kg} \mathrm{ha}^{-1}$ of ammonium sulfate ( $40 \mathrm{~kg} \mathrm{ha}^{-1}$ of $\mathrm{N}$ and $44 \mathrm{~kg} \mathrm{ha}^{-1}$ of $\left.\mathrm{SO}_{4}\right)$ at 15 and $35 \mathrm{DAE}$, and $5 \mathrm{~L} \mathrm{ha}^{-1}$ of Mn, $2 \mathrm{~L} \mathrm{ha}^{-1}$ of B, $1 \mathrm{~L} \mathrm{ha}^{-1}$ of $\mathrm{Zn}$, and $4 \mathrm{~L} \mathrm{ha}^{-1}$ of amino acids applied thrice throughout the crop cycle $(20,40$ and 60 DAE). The amino acids applied and their respective concentrations were: L-glycine (5.08\%), L-proline (2.94\%), L-alanine $(2.02 \%)$, L-aspartic acid (1.34\%), L-arginine (1.65\%), L-serine $(0.65 \%)$, L-leucine $(0.65 \%)$, and L-lysine $(0.48 \%)$. The experiment was maintained free of pests and weeds through chemical control and manual weeding, respectively.

The experiment was arranged in a randomized complete block design, in a $4 \times 2$ factorial arrangement with four replicates, in which four biostimulant managements [control, without the application; Silicon (Si); biostimulant (Veritas); and $\mathrm{Si}+$ biostimulant (Veritas)] were evaluated in two cotton varieties (FM 954GLT and FM 983GLT). The treatments were composed of four applications of $2.5 \mathrm{~kg} \mathrm{ha}^{-1}$ of Si and $1 \mathrm{~L} \mathrm{ha}^{-1}$ of biostimulant.

The experiment installation occurred 40 days after the emergence (DAE) during the first application, and the other applications occurred at 60,80 and $100 \mathrm{DAE}$. The applications were carried out using a $\mathrm{CO}_{2}$-pressurized backpack sprayer $\left(2 \mathrm{kgf} \mathrm{cm}^{-2}\right)$ coupled to a bar containing four XR 110.02 flat jet tips, with a flow rate of $200 \mathrm{~L}$ $\mathrm{ha}^{-1}$ of the mixture. The applications occurred in the morning with the temperature between 22 and $26{ }^{\circ} \mathrm{C}$, and $60 \%$ of relative humidity of the upper air.

Data collection occurred at 120 DAE for electrolyte leakage, relative water content and nutrient contents in the leaves, and at 195 DAE for harvest and technological quality of the fiber, adopting the methodologies described below.

Considering the analysis of electrolyte leakage, the methodology proposed by Campos and Thi (1997) was adjusted using a copper drill to obtain ten leaf disks of $25 \mathrm{~mm}^{2}$ each per experimental unit, which were washed and conditioned in beakers containing $20 \mathrm{~mL}$ of deionized water. After sealing with aluminum foil, the beakers were conditioned at $25^{\circ} \mathrm{C}$ for 90 minutes and the initial conductivity of the medium (Xi) was measured using a benchtop conductivity meter. Subsequently, the beakers were subjected to a temperature of $80{ }^{\circ} \mathrm{C}$ for 90 minutes in a drying oven, and, after cooling the contents of the beakers the final conductivity (Xf) was measured. The electrolyte leakage was expressed as the percentage of conductivity in relation to the total conductivity after the exposure to the temperature of $80^{\circ} \mathrm{C}$ per 90 minutes, as expressed in the equation:

$$
\text { Electrolyte leakage }=[(X i / X f) \times 100]
$$

Using a puncher $\left(10 \mathrm{~mm}^{2}\right), 10$ discs were removed from the diagnostic leaf in the basipetal direction of the plant, and the fresh matter (FM) of this material was recorded on an analytical balance. The disks were then transferred 
to beakers of $100 \mathrm{~mL}$ and submerged in deionized water for 24 hours to obtain the turgid mass of the material (TM). Afterwards, the discs were dried in a forced air oven at $70{ }^{\circ} \mathrm{C}$ for 48 hours to obtain their dry matter (DM), and the relative water content (RWC) was determined based on the following equation (Weatherley, 1950):

$$
R W C=(F M-D M) /(T M-D M) \times 100
$$

The determination of the macro and micronutrient contents were performed at 120 DAE, where 20 diagnostic leaves were collected per plot and determined the contents of nitrogen $(\mathrm{N})$, potassium $(\mathrm{K})$, calcium $(\mathrm{Ca})$, magnesium $(\mathrm{Mg})$, sulfur $(\mathrm{S})$, copper $(\mathrm{Cu})$, manganese $(\mathrm{Mn})$, zinc $(\mathrm{Zn})$, boron $(\mathrm{B})$ and silicon $(\mathrm{Si})$, following the criteria of diagnostic leaf classification described by Silva (1999).

The manual harvesting of the plot areas was carried out in order to evaluate the cotton productivity. Afterward, the material was weighed and the final yield was extrapolated to $\mathrm{kg} \mathrm{ha}^{-1}$ following the methodology proposed by Santos et al. (2014).

The analysis of the technological characteristics of the fiber was carried out in the laboratory. Hence, 50 bolls of the middle third of the cotton plants were collected and de-stoned for this purpose and evaluated by HVI (High Volume Instrument) of the brand Zellweger Uster/Spinlab, series 900. The following variables were determined: micronaire index (MIC), fiber length (UHML), rupture strength (STR), length uniformity (UNF), fiber elongation (ELG), and short fiber index (SFI).

The data were submitted to analysis of variance by the F test and the means were compared by the Tukey test at $5 \%$ of probability using the software Sisvar 5.5 (Ferreira, 2011).

\section{Results and Discussion}

The variables leaf K content, UHML, UNF, and SFI showed differences between the two cotton varieties, while the biostimulant treatments influenced only the variables $\mathrm{N}, \mathrm{Mg}, \mathrm{Fe}, \mathrm{B}, \mathrm{Si}$, and electrolyte leakage. The interaction variety $\mathrm{x}$ biostimulant management was significant for $\mathrm{N}$ and $\mathrm{Mn}$ contents, and for the other variables, it was not observed differences between the sources of variation evaluated (Table 1). 
Table 1. Analysis of variance for the contents of nitrogen $(\mathrm{N})$, phosphorus $(\mathrm{P})$, potassium $(\mathrm{K})$, calcium $(\mathrm{Ca})$, magnesium $(\mathrm{Mg})$, sulfur $(\mathrm{S})$, copper $(\mathrm{Cu})$, iron $(\mathrm{Fe})$, manganese $(\mathrm{Mn})$, zinc $(\mathrm{Zn})$, boron $(\mathrm{B})$, and silicon $(\mathrm{Si})$, relative water content (RWC), electrolyte leakage (EXT), micronaire index (MIC), fiber length (UHML), rupture strength (STR), length uniformity (UNF), fiber elongation (ELG), short fiber index (SFI) and yield (PROD) of two cotton cultivars submitted to the application of biostimulants. Luís Eduardo Magalhães-BA, 2017

\begin{tabular}{|c|c|c|c|c|c|c|c|}
\hline \multirow{3}{*}{ Source of variation } & \multirow{3}{*}{ D.F. } & \multicolumn{6}{|c|}{ Mean Squares } \\
\hline & & \multicolumn{6}{|c|}{ Macronutrients } \\
\hline & & $\mathrm{N}$ & $\mathrm{P}$ & $\mathrm{K}$ & $\mathrm{Ca}$ & $\mathrm{Mg}$ & $\mathrm{S}$ \\
\hline Variety $(\mathrm{V})$ & 1 & $3.125^{\mathrm{ns}}$ & $0.031^{\mathrm{ns}}$ & $34.031^{*}$ & $13.781^{\mathrm{ns}}$ & $4.500^{\mathrm{ns}}$ & $0.125^{\mathrm{ns}}$ \\
\hline Management (M) & 3 & $22.041^{*}$ & $0.197^{\text {ns }}$ & $13.281^{\mathrm{ns}}$ & $16.447^{\mathrm{ns}}$ & $9.375^{*}$ & $0.125^{\mathrm{ns}}$ \\
\hline $\mathrm{V} \times \mathrm{B}$ & 3 & $23.708^{*}$ & $0.197^{\text {ns }}$ & $17.197^{\mathrm{ns}}$ & $5.614^{\mathrm{ns}}$ & $2.583^{\mathrm{ns}}$ & $0.458^{\mathrm{ns}}$ \\
\hline Block & 3 & $1.208^{\mathrm{ns}}$ & $0.114^{\mathrm{ns}}$ & $7.531^{\mathrm{ns}}$ & $2.281^{\mathrm{ns}}$ & $5.208^{\mathrm{ns}}$ & $0.041^{\mathrm{ns}}$ \\
\hline Error & 21 & 5.136 & 0.162 & 5.721 & 9.424 & 2.565 & 0.232 \\
\hline $\mathrm{CV}(\%)$ & & 5.97 & 13.57 & 16.11 & 8.55 & 18.98 & 14.55 \\
\hline \multirow{2}{*}{ Source of variation } & \multirow{2}{*}{ D.F. } & \multicolumn{6}{|c|}{ Micronutrients } \\
\hline & & $\mathrm{Cu}$ & $\mathrm{Fe}$ & $\mathrm{Mn}$ & $\mathrm{Zn}$ & $\mathrm{B}$ & $\mathrm{Si}$ \\
\hline Variety $(\mathrm{V})$ & 1 & $0.031^{\mathrm{ns}}$ & $105.125^{\mathrm{ns}}$ & $66.125^{\mathrm{ns}}$ & $0.781^{\mathrm{ns}}$ & $1.531^{\mathrm{ns}}$ & $0.031^{\mathrm{ns}}$ \\
\hline Management (M) & 3 & $1.031^{\mathrm{ns}}$ & $441.750^{*}$ & $593.666^{*}$ & $16.781^{\mathrm{ns}}$ & $192.864^{*}$ & $0.531^{*}$ \\
\hline $\mathrm{V} \times \mathrm{B}$ & 3 & $0.031^{\mathrm{ns}}$ & $102.375^{\mathrm{ns}}$ & $437.458^{*}$ & $20.614^{\mathrm{ns}}$ & $119.531^{\mathrm{ns}}$ & $0.197^{\mathrm{ns}}$ \\
\hline Block & 3 & $0.0531^{\mathrm{ns}}$ & $349.916^{\mathrm{ns}}$ & $189.583^{\mathrm{ns}}$ & $21.197^{\mathrm{ns}}$ & $15.614^{\mathrm{ns}}$ & $0.197^{\mathrm{ns}}$ \\
\hline Error & 21 & 0.816 & 140.011 & 131.607 & 13.007 & 59.186 & 0.126 \\
\hline $\mathrm{CV}(\%)$ & & 16.53 & 9.85 & 17.86 & 12.61 & $17.37^{-}$ & 5.52 \\
\hline \multirow{2}{*}{ Source of variation } & \multirow{2}{*}{ D.F. } & \multicolumn{6}{|c|}{ Technological Quality of the fiber } \\
\hline & & MIC & UHML & STR & UNF & ELG & SFI \\
\hline Variety $(\mathrm{V})$ & 1 & $0.281^{\mathrm{ns}}$ & $13.781^{* *}$ & $3.125^{\mathrm{ns}}$ & $36.125^{* *}$ & $0.281^{\mathrm{ns}}$ & $57.781^{* *}$ \\
\hline Bioestimulant (B) & 3 & $0.031^{\mathrm{ns}}$ & $0.281^{\mathrm{ns}}$ & $1.708^{\mathrm{ns}}$ & $1.875^{\mathrm{ns}}$ & $0.114^{\mathrm{ns}}$ & $0.364^{\mathrm{ns}}$ \\
\hline $\mathrm{V} \times \mathrm{B}$ & 3 & $0.281^{\mathrm{ns}}$ & $0.364^{\mathrm{ns}}$ & $0.375^{\mathrm{ns}}$ & $0.875^{\mathrm{ns}}$ & $0.114^{\mathrm{ns}}$ & $0.114^{\mathrm{ns}}$ \\
\hline Block & 3 & $0.197^{\mathrm{ns}}$ & $1.614^{\mathrm{ns}}$ & $2.08^{\mathrm{ns}}$ & $1.208^{\mathrm{ns}}$ & $0.031^{\mathrm{ns}}$ & $0.614^{\mathrm{ns}}$ \\
\hline Error & 21 & 0.245 & 0.590 & 2.613 & 2.184 & 0.150 & 0.459 \\
\hline $\mathrm{CV}(\%)$ & & 12.49 & 2.56 & 5.23 & 1.82 & 6.50 & 7.20 \\
\hline \multirow{2}{*}{ Source of variation } & \multirow{2}{*}{ D.F. } & \multicolumn{6}{|c|}{ Physiological variables and crop productivity } \\
\hline & & RWC & & EXT & & PROD & \\
\hline Variety $(\mathrm{V})$ & 1 & $112.500^{\mathrm{ns}}$ & & $5.281^{\mathrm{ns}}$ & & 604725.03 & \\
\hline Management (M) & 3 & $253.208^{\mathrm{ns}}$ & & $46.364^{* *}$ & & 10548.947 & \\
\hline $\mathrm{V} \times \mathrm{M}$ & 3 & $152.250^{\mathrm{ns}}$ & & $0.947^{\mathrm{ns}}$ & & 232880.53 & \\
\hline Block & 3 & $56.375^{\mathrm{ns}}$ & & $4.114^{\mathrm{ns}}$ & & 462326.61 & \\
\hline Error & 21 & 85.994 & & 2.662 & & 156571.73 & \\
\hline $\mathrm{CV}(\%)$ & & 11.11 & & 9.18 & & 6.63 & \\
\hline
\end{tabular}

Note. ${ }^{* *}$ significant at $1 \%$ of probability $(\mathrm{p}<0.01),{ }^{*}$ significant at $5 \%$ of probability $(0.01 \leq \mathrm{p}<0.05)$, ns not significant $(\mathrm{p} \geq 0.05)$. D.F.: Degrees of freedom.

Under the conditions of this study, it was verified that there were no differences for the contents of $\mathrm{P}, \mathrm{K}, \mathrm{Ca}$, and $\mathrm{S}$, and only the $\mathrm{Mg}$ content was significant (Table 2). According to the range of leaf nutrient content sufficiency for the cotton crop established by Kurihara et al. (2013), the values observed in this study are considered low for $\mathrm{S}$, sufficient for $\mathrm{P}$ and $\mathrm{K}$, high for $\mathrm{Ca}$ and in excess for $\mathrm{Mg}$, both for the isolated application and in the silicon + biostimulant mixture. However, the content of $\mathrm{Mg}$ in the leaf observed for the control treatment, $9.87 \mathrm{~g} \mathrm{~kg}^{-1}$, was higher than when the biostimulant was applied, $7.25 \mathrm{~g} \mathrm{~kg}^{-1}$, and this possibly occurs because the product used favors the assimilation of $\mathrm{Ca}$, which possibly reduced the leaf $\mathrm{Mg}$ content.

Regarding the two cotton cultivars studied, only the content of $\mathrm{K}$ showed differences between them, with $\mathrm{K}$ contents in the FM 954GLT and FM 983GLT varieties being equal to 15.87 and $13.81 \mathrm{~g} \mathrm{~kg}^{-1}$, respectively, which correspond to a difference of $14 \%$. In spite of the difference between the varieties, $\mathrm{K}$ levels are considered adequate for the crop, so this difference should be associated to the required level of each genetic material (variety) since potassium fertilization was based on the crop necessity. 
Table 2. Contents of the macronutrients phosphorus $(\mathrm{P})$, potassium $(\mathrm{K})$, calcium $(\mathrm{Ca})$, magnesium $(\mathrm{Mg})$, and sulfur (S) in the leaves of cotton plants treated with biostimulants and silicon at 120 days after emergence. Luís Eduardo Magalhães-BA, 2017

\begin{tabular}{llllll}
\hline Source of variation & $\mathrm{P}$ & $\mathrm{K}$ & $\mathrm{Ca}$ & $\mathrm{Mg}$ & $\mathrm{S}$ \\
\hline & -0 & & & \\
Biostimulants & & & & \\
Control & $3.00 \mathrm{a}$ & $14.50 \mathrm{a}$ & $35.75 \mathrm{a}$ & $9.87 \mathrm{a}$ & $3.12 \mathrm{a}$ \\
Silicon (Si) & $2.75 \mathrm{a}$ & $14.12 \mathrm{a}$ & $36.50 \mathrm{a}$ & $8.37 \mathrm{ab}$ & $3.37 \mathrm{a}$ \\
Veritas (Ve) & $3.12 \mathrm{a}$ & $14.00 \mathrm{a}$ & $37.37 \mathrm{a}$ & $7.25 \mathrm{~b}$ & $3.37 \mathrm{a}$ \\
$\mathrm{Si}+\mathrm{Ve}$ & $3.00 \mathrm{a}$ & $16.75 \mathrm{a}$ & $34.00 \mathrm{a}$ & $8.25 \mathrm{ab}$ & $3.37 \mathrm{a}$ \\
Varieties & & & & & \\
FM 983GLT & $2.93 \mathrm{a}$ & $13.81 \mathrm{~b}$ & $36.56 \mathrm{a}$ & $8.06 \mathrm{a}$ & $3.25 \mathrm{a}$ \\
FM 954GLT & $3.00 \mathrm{a}$ & $15.87 \mathrm{a}$ & $35.25 \mathrm{a}$ & $8.81 \mathrm{a}$ & $3.37 \mathrm{a}$ \\
\hline
\end{tabular}

Note. * Means followed by the same letter in the column do not differ by Tukey test at $5 \%$ of probability.

The micronutrient contents in the leaves were considered low for $\mathrm{Cu}$, sufficient for $\mathrm{Zn}$, suitable for $\mathrm{B}$ and high for Fe, according to the sufficiency levels proposed by Kurihara et al. (2013). The varieties did not show variation in the nutritional content of micronutrients (Table 3 ).

Table 3. Split of the interaction varieties $\times$ biostimulant and silicon management for the contents of nitrogen $(\mathrm{N})$ and manganese $(\mathrm{Mn})$ in the leaves of cotton plants treated with biostimulant and silicon at 120 days after emergence. Luís Eduardo Magalhães-BA, 2017

\begin{tabular}{|c|c|c|c|c|c|}
\hline Source of variation & $\mathrm{Cu}$ & $\mathrm{Fe}$ & $\mathrm{Zn}$ & $\mathrm{B}$ & $\mathrm{Si}$ \\
\hline & ------ & - & ---- mg & & \\
\hline \multicolumn{6}{|l|}{ Biostimulants } \\
\hline Control & $5.00 \mathrm{a}$ & $114.50 \mathrm{c}$ & $29.75 a$ & $50.00 \mathrm{a}$ & $0.50 \mathrm{~b}$ \\
\hline Silicon (Si) & $5.75 \mathrm{a}$ & $115.25 \mathrm{c}$ & $26.75 \mathrm{a}$ & $44.62 \mathrm{ab}$ & $0.62 \mathrm{ab}$ \\
\hline Veritas (Ve) & $5.75 \mathrm{a}$ & $120.15 b$ & $28.12 \mathrm{a}$ & $44.50 \mathrm{ab}$ & $1.00 \mathrm{a}$ \\
\hline $\mathrm{Si}+\mathrm{Ve}$ & $5.37 \mathrm{a}$ & $130.62 \mathrm{a}$ & $29.75 a$ & $38.00 \mathrm{~b}$ & $1.00 \mathrm{a}$ \\
\hline \multicolumn{6}{|l|}{ Varieties } \\
\hline FM 983GLT & $5.50 \mathrm{a}$ & $118.31 \mathrm{a}$ & $28.43 \mathrm{a}$ & $44.06 \mathrm{a}$ & $0.75 \mathrm{a}$ \\
\hline FM 954GLT & $5.43 \mathrm{a}$ & $121.93 \mathrm{a}$ & $28.75 \mathrm{a}$ & $44.05 \mathrm{a}$ & $0.81 \mathrm{a}$ \\
\hline
\end{tabular}

Note.* Means followed by the same letter in the column do not differ by Tukey test at $5 \%$ of probability.

The management of $\mathrm{Si}$ and biostimulant did not affect the contents of $\mathrm{Cu}$ and $\mathrm{Zn}$. The content of $\mathrm{Fe}$, however, was higher in the treatment that received the application of $\mathrm{Si}+$ biostimulant, with $130.62 \mathrm{mg} \mathrm{kg}^{-1}$, followed by the treatment with the application of biostimulant alone, which presented $120.15 \mathrm{mg} \mathrm{kg}^{-1}$ of Fe. The most interesting aspect of this result is the potentiation of the increase of Fe content in the leaf provided by the synergistic action of $\mathrm{Si}+$ biostimulant. According to Srivastava et al. (2016), biostimulants increase the capacity of nutrient accumulation by plants when used without the association with other products. However, there are no reports of this synergism with $\mathrm{Si}$, thus, new research should be carried out to understand this behavior.

Contrary to the behavior presented for $\mathrm{Fe}$, the management of $\mathrm{Si}+$ biostimulant reduced the content of $\mathrm{B}$ by $31 \%$ when compared to the control treatment, showing B contents of 38.00 and $50.00 \mathrm{mg} \mathrm{kg}^{-1}$, respectively (Table 3). Boron is an element preferentially absorbed via the non-metabolic passive process, and the elevation of the transpiration and cell wall extensibility are the main mechanisms used for this nutrient assimilation (Hu \& Brown, 1994; Hu \& Brown, 1997). Thus, the application of $\mathrm{Si}+$ biostimulant aiming the reduction of transpiration and extensibility of the cell wall via accumulation of $\mathrm{Si}$ and $\mathrm{Ca}$ may have interfered in the main processes of B assimilation and, consequently, decreased its content in cotton leaves.

The application of $\mathrm{Si}+$ biostimulant and only biostimulant presented higher Si contents than the control treatment (Table 3). The control treatment presented $0.50 \mathrm{mg} \mathrm{kg}^{-1}$ of $\mathrm{Si}$, while the use of biostimulant and $\mathrm{Si}+$ biostimulant showed contents of $\mathrm{Si}$ equal to $1.00 \mathrm{mg} \mathrm{kg}^{-1}$. It is important to note that these levels represent a 
decrease of $50 \%$ of $\mathrm{Si}$ in the leaves when there is no biostimulant application. This is an indication that the biostimulant stimulates the elevation of this nutrient in the leaves, even in comparison to the foliar pulverization of Si.

The increase of nutrient assimilation due to the application of biostimulant is constantly reported in the literature, however, there is no record that the foliar pulverization of this nutrient is less effective than the stimulus caused by the biostimulant in absorbing the element. Perhaps, in the case of Si, this occurs due to the characteristics of essentiality of this nutrient in the cotton crop or because of the stimulation of the alternative $\mathrm{Si}$ assimilation routes described by Reynolds et al. (2016).

The content of $\mathrm{N}$ in the leaves, regarding the split of the interaction cultivars $\mathrm{x}$ biostimulant management, showed differences between varieties only when the biostimulant was applied, being the $\mathrm{N}$ content of the variety FM 983GLT (41.50 $\mathrm{g} \mathrm{kg}^{-1}$ ) 15\% higher than the content observed for the FM 954GLT (36.00 $\left.\mathrm{g} \mathrm{kg}^{-1}\right)$. In relation to the content of $\mathrm{Mn}$, the difference was verified only in the control treatments, being the Mn content higher in the leaves of the FM 983GLT variety, with $85.25 \mathrm{~g} \mathrm{~kg}^{-1}$. These results indicate that the cultivar FM 983GLT is more responsive to the stimulation of $\mathrm{N}$ absorption via biostimulant and more demanding in Mn. However, the FM 954GLT variety, when stimulated with biostimulants responds similarly to FM 983GLT in relation to the content of Mn in the leaves (Table 4).

Table 4. Split of the interaction varieties $\times$ biostimulant and silicon management for the contents of nitrogen $(\mathrm{N})$ and manganese $(\mathrm{Mn})$ in the leaves of cotton plants treated with biostimulant and silicon at 120 days after emergence. Luís Eduardo Magalhães-BA, 2017

\begin{tabular}{|c|c|c|c|c|}
\hline \multirow{2}{*}{ Biostimulants } & \multicolumn{4}{|c|}{ Cultivar } \\
\hline & FM 983GLT & FM 954GLT & FM 983GLT & FM 954GLT \\
\hline & \multicolumn{2}{|c|}{ 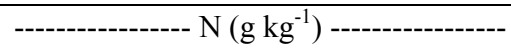 } & \multicolumn{2}{|c|}{ - } \\
\hline Control & $37.00 \mathrm{aB}$ & $36.50 \mathrm{aB}$ & $85.25 \mathrm{aA}$ & $66.75 \mathrm{bA}$ \\
\hline Silicon (Si) & $35.75 \mathrm{aB}$ & $37.00 \mathrm{aB}$ & $59.25 \mathrm{aB}$ & $52.25 \mathrm{aA}$ \\
\hline Veritas (Ve) & $41.50 \mathrm{aA}$ & $36.00 \mathrm{bB}$ & $56.00 \mathrm{bB}$ & $73.00 \mathrm{aA}$ \\
\hline $\mathrm{Si}+\mathrm{Ve}$ & $38.75 \mathrm{aAB}$ & $41.00 \mathrm{aA}$ & $62.20 \mathrm{aB}$ & $59.25 \mathrm{aA}$ \\
\hline
\end{tabular}

Note. * Means followed by the same uppercase letter in the column and same lowercase letter in the line do not differ by Tukey test at $5 \%$ of probability.

When analyzing the effect of the management within each variety, it is verified that the FM 954GLT variety presents higher $\mathrm{N}$ levels when the biostimulant is applied compared to the control and Si treatments, whereas for FM 983GLT the higher $\mathrm{N}$ content in the leaves is verified when $\mathrm{Si}+$ biostimulant was applied (Table 4). This result is in agreement with Nardi et al. (2016), who state that the application of biostimulants increases the activity of nitrogen metabolism in the plant, mainly through the activity of the enzymes of the nitrogenase complex and increase of chlorophyll.

The content of $\mathrm{Mn}$ in the leaves was higher in the control treatment than in the Si and biostimulant managements for the variety FM 983GLT, whereas there was no variation in the Mn content for the variety FM 954GLT regarding the type of management (Table 4). According to Sahebi et al. (2017), the reduction of Mn content when Si was applied occurs, indirectly, because of the fact that $\mathrm{Si}$ increases the capacity of $\mathrm{P}$ assimilation in plants, and as a consequence, there is a reduction in Mn availability. However, the reduction in the content of Mn caused by the application of the biostimulant is not fully understood, and new studies should be carried out to analyze how the $\mathrm{CaT}^{\mathrm{TM}}$ technology interacts with the mechanisms of Mn assimilation.

The application of biostimulant and/or silicon did not interfere in the relative water content nor in the yield of the cotton crop (Table 5). However, the treatments that received the application of just silicon or in mixture with the biostimulant presented electrolyte leakage $24 \%$ lower than the values observed for the control treatment, whereas the biostimulant presented a reduction of only $11 \%$. This result validates the efficiency of both biostimulant and silicon in maintaining the integrity of the plants' cell wall, but the silicon is more efficient than the biostimulant. 
Table 5. Relative water content (RCW), electrolyte leakage (EXT), and productivity (PROD) of the cotton crop submitted to the application of biostimulant in the treatment of seeds. Luís Eduardo Magalhães-BA, 2015

\begin{tabular}{|c|c|c|c|}
\hline Source of variation & RWC & EXT & PRO \\
\hline & \multicolumn{2}{|c|}{ 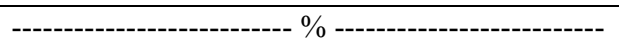 } & -------- kg ha ${ }^{-1}$ \\
\hline \multicolumn{4}{|c|}{ 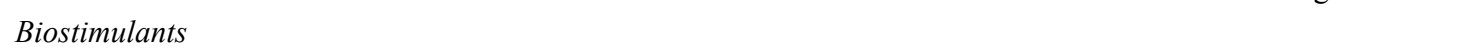 } \\
\hline Control & $85.00 \mathrm{a}$ & $20.87 \mathrm{a}$ & $5961.75 a$ \\
\hline Silicon (Si) & $75.12 \mathrm{a}$ & $16.00 \mathrm{c}$ & $5988.50 \mathrm{a}$ \\
\hline Veritas (Ve) & $86.25 \mathrm{a}$ & $18.50 \mathrm{~b}$ & $5922.37 \mathrm{a}$ \\
\hline $\mathrm{Si}+\mathrm{Ve}$ & $87.37 \mathrm{a}$ & $15.75 \mathrm{c}$ & $6005.75 a$ \\
\hline \multicolumn{4}{|l|}{ Varieties } \\
\hline FM 983GLT & $81.56 \mathrm{a}$ & $18.18 \mathrm{a}$ & $5832.12 \mathrm{a}$ \\
\hline FM 954GLT & $85.31 \mathrm{a}$ & $17.37 \mathrm{a}$ & $6107.06 \mathrm{a}$ \\
\hline
\end{tabular}

Note. * Means followed by the same letter in the column do not differ by Tukey test at $5 \%$ of probability.

This result corroborates the main lines of research that illustrate the efficiency of Si in overcoming the effects of biotic and abiotic stresses. Luyckx et al. (2017), for instance, report that Si is capable of suppressing the harmful effects of drought, high temperature, frost, salinity and, nutritional imbalance. According to Sahebi et al. (2015), these effects occur due to the fact that $\mathrm{Si}$ application increases the activity of the enzymes superoxide dismutase, guaiacol peroxidase, ascorbate peroxidase, and dehydroascorbate reductase. Biostimulants also act by increasing the activity of the antioxidant complex enzymes (Nardi et al., 2015) as a way to increase the cell wall integrity and decrease the leakage of ions from the cells.

The yields for both management and varieties were not statistically altered (Table 5). This result corroborates those described by Silva et al. (2016), who compared several biostimulants in the cotton crop and did not find out any differences between the treatments tested. In general, the changes caused by biostimulants in the cotton crop are related to the plant metabolism and do not always manifest in the form of increased production.

Reports of Si efficiency on the increase of cotton crop productivity are limited, especially regarding foliar pulverization. The most expressive study in relation to the increase of crop yield promoted by the application of Si was carried out by Boylston et al. (1990), who observed an increase of $12 \%$ in the yield.

The isolated or combined application of biostimulant and silicon did not influence the technological quality of the cotton fiber (Table 6). This result does not corroborate Silva et al. (2016), and Luyckx et al. (2017), who report that the application of biostimulants and silicon, respectively, alter the technological characteristics of the fiber. However, the biostimulant action is directly related to the active ingredients the product contains and products of different natures can induce different responses by plants.

Table 6. Micronaire index (MIC), fiber length (UHML), rupture strength (STR), length uniformity (UNF), fiber elongation (ELG), and short fiber index (SFI) of the cotton crop submitted to the application of biostimulants in the treatment of seeds. Luís Eduardo Magalhães-BA, 2015

\begin{tabular}{|c|c|c|c|c|c|c|}
\hline Source of variation & $\mathrm{MIC}$ & UHML & STR & UI & ELG & SFI \\
\hline & -- $\mu \mathrm{g} \mathrm{pol}^{-1}--$ & ---- mm ---- & -- gf tex ${ }^{-1}-$ & --------- & ------ 9 & 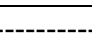 \\
\hline \multicolumn{7}{|l|}{ Biostimulants } \\
\hline Control & $4.00 \mathrm{a}$ & $30.12 \mathrm{a}$ & $30.87 \mathrm{a}$ & $81.25 \mathrm{a}$ & $6.12 \mathrm{a}$ & $9.75 \mathrm{a}$ \\
\hline Silicon $(\mathrm{Si})$ & $4.00 \mathrm{a}$ & $29.87 \mathrm{a}$ & $31.00 \mathrm{a}$ & $80.87 \mathrm{a}$ & $6.00 \mathrm{a}$ & $9.50 \mathrm{a}$ \\
\hline Veritas (Ve) & $3.87 \mathrm{a}$ & $29.75 a$ & $30.37 \mathrm{a}$ & $81.62 \mathrm{a}$ & $6.25 \mathrm{a}$ & $9.87 \mathrm{a}$ \\
\hline $\mathrm{Si}+\mathrm{Ve}$ & $4.00 \mathrm{a}$ & $30.12 \mathrm{a}$ & $31.50 \mathrm{a}$ & $80.50 \mathrm{a}$ & $6.25 \mathrm{a}$ & $10.00 \mathrm{a}$ \\
\hline \multicolumn{7}{|l|}{ Varieties } \\
\hline FM 983GLT & $4.06 \mathrm{a}$ & $29.31 b$ & $31.25 \mathrm{a}$ & $80.00 \mathrm{~b}$ & $6.06 \mathrm{a}$ & $11.12 \mathrm{a}$ \\
\hline FM 954GLT & $3.87 \mathrm{a}$ & $30.62 \mathrm{a}$ & $30.62 \mathrm{a}$ & $82.20 \mathrm{a}$ & $6.25 \mathrm{a}$ & $8.43 b$ \\
\hline
\end{tabular}

Note. * Means followed by the same letter in the column do not differ by Tukey test at 5\% of probability.

The contents of $\mathrm{Si}$ in the cotton fiber rise during the second phase of fiber formation, during the elongation, reaching a maximum level in the tertiary phase of secondary wall deposition and the beginning of fiber 
maturation (Ferreira, 2008). Despite the evidence that silicon acts directly in the fiber formation process, in the present study the foliar application of this element did not interfere in the aspect of quality, and perhaps, in soil applications, the efficiency of the product is superior, just as reported by Boylston et al. (1990).

The cultivar FM 954GLT presented higher fiber length and uniformity, and lower short fiber index than the cultivar FM 983GLT (Table 6). Cotton cultivars have distinct fiber quality, mainly because that the characteristics that constitute the fiber classification are directly connected to the genotype (Saleem et al., 2011). However, according to Freire et al. (2017), the quality of the plume produced in the West of Bahia in the 2016/17 crop year is considered of great quality, being the micronaire index from 3.8 to $4.1 \mu \mathrm{g} \mathrm{pol}^{-1}$, fiber length ranging from 28.9 to $29.9 \mathrm{~mm}$, rupture strength from 28.0 to $29.9 \mathrm{gf} \mathrm{tex}^{-1}$, length uniformity from 80.0 to $81.9 \%$ and, short fiber index ranging from 6.0 a $9.9 \%$, the values most observed for the varieties FM 983GLT and FM 954GLT.

\section{Conclusions}

The management of Si and biostimulant decreased the levels of B and Mn in cotton leaves. However, there was an increase in the cell wall integrity, and in the contents of N, Fe, and $\mathrm{Si}$ in the leaves. Despite the positive effects, and these were related to the best nutrition of the plant, there was no change in yield and fiber quality. This means that the application of $\mathrm{Si}$ and biostimulants in the cotton crop may not be characterized as the best management of the crop since it will not result in an economic return to the producer.

The differences in the contents of N, K, and Mn in the leaves of the varieties FM 983GLT and FM 954GLT are related to the genetic characteristics of each material, so it is important to point out the correct choice of the cotton cultivar for the use in specific producing areas. The genetic characteristics of the variety may be better explored in regions to which they are already adapted, resulting in better yield and fiber quality results.

\section{References}

Boylton, E. K., Hebert, J. J., Hensarling, T. P., Bradow, J. M., \& Thibodeaux, D. P. (1990). Role of silicon in developing cotton fibers. Journal of Plant Nutrition, 11(12), 1739-1747. https://doi.org/10.1080/01904169 009364063

Campos, P. S., \& Thi, A. T. P. (1997). Effect of abscisic acid pretreatment on membrane leakage and lipid composition of Vigna unguiculata leaf discs subject to osmotic stress. Plant Science, 130(1), 11-18. https://doi.org/10.1016/S0168-9452(97)00199-4

Collin, B., Doelsch, E., Keller, C., \& Panfili, F. (2012). Distribution and variability of silicon, copper, and zinc in different bamboo species. Plant \& Soil, 351(1-2), 377-387. https://doi.org/10.1007/s11104-011-0974-9

CONAB (Companhia Nacional de Abastecimento). (2017). Acompanhamento da safra brasileira de grãos, Safra 2016/17-Décimo primeiro levantamento. Brasília, DF: CONAB. Retrieved from https://www.conab.gov. br/OlalaCMS/uploads/arquivos/17_07_12_11_17_01_boletim_graos_julho_2017.pdf

Farooq, M. A., Ali, S., Hameed, A., Ishaque, W., Mahmood, K., \& Igbal, Z. (2013). Alleviation of cadmium toxicity by silicon is related to elevated photosynthesis, antioxidant enzymes; suppressed cadmium uptake and oxidative stress in cotton. Ecotoxicology \& Environmental Safety, 96(4), 242. https://doi.org/10.1016/ j.ecoenv.2013.07.006

Freire, E. C., Brentano, S. A., Araújo, C. A., Pedrosa, M. B., \& Ortega, R. P. (2017). Qualidade de fibras de cultivares de algodão avaliadas comercialmente. Safra 2016/2017. Divulgação dos resultados de pesquisas safra 2017/17. Luis Eduardo Magalhães, BA: Fundação BA.

Hu, H., \& Brown, P. H. (1994). Localization of boron in cell walls of squash and tobacco and its association with pectin. Plant Physiology, 105, 681-689. https://doi.org/10.1104/pp.105.2.681

Hu, H., \& Brown, P. H. (1997). Absorption of boron by plant roots. Plant \& Soil, 193(1-2), 49-58. https://doi.org/10.1023/A:1004255707413

Kurihara, C. H., Venegas, V. H. A., Neves, J. C. L., Novais, R. F., \& Staut, L. A. (2013). Faixas de suficiência para teores foliares de nutrientes em algodão e em soja, definidas em função de índices DRIS. Biochemical Education, 60(3), 412-419. https://doi.org/10.1590/S0034-737X2013000300015

Luyckx, M., Hausman, J. F., Lutts, S., \& Guerriero, G. (2017). Silicon and plants: Current knowledge and technological perspectives. Frontiers in Plant Science, 8(19), 411. https://doi.org/10.3389/fpls.2017.00411 
Nardi, S., Pizzehello, D., Schiavon, M., \& Ertani, A. (2016). Plant biostimulants: Physiological responses induced by protein hydrolyzed-based products and humic substances in plant metabolism. Sci. Agric, 73(1), 18-23. https://doi.org/10.1590/0103-9016-2015-0006

Reynolds, O. L., Padula, M. P., Zeng, R., \& Gurr, G. M. (2016). Silicon: Potential to promote direct and indirect effects on plant defense against arthropod pests in agriculture. Frontiers in Plant Science, 7(73). https://doi.org/10.3389/fpls.2016.00744

Sahebi, M., Hanafi, M. M., Siti, N. A. A., Rafii, M. Y., Azizi, P., Tengoua, F. F., ... Shabanimofrad, M. (2017). Importance of silicon and mechanisms of biosilica formation in plants. Biomed Research International, 2015, 396010. https://doi.org/10.1155/2015/396010

Saleem, M. F., Cheema, M. A., Bilal, M. F., Anjum, S. A., Shahid, M. Q., \& Khurshid, I. (2011). Fiber quality of cotton (Gossypium hirsutum) cultivars under different phosphorus levels. The Journal of Animal \& Plant Sciences, 21, 26-30.

Silva, R. A., Santos, J. L., Oliveira, L. S., Soares, M. R. S., \& Santos, S. M. S. (2016). Biostimulants on mineral nutrition and fiber quality of cotton crop. Rev. Bras. Eng. Agric. Ambient, 12(20), 1062. https://doi.org/10.1590/1807-1929/agriambi.v20n12p1062-1066

Soares, L. H., Neto, D. D., Fagan, E. B., Teixeira, W. F., \& Pereira, I. S. (2017). Physiological, phenometric and productive changes in soybean crop due to the use of kinetin. Pesquisa Agropecuária Tropical, 47(1), 80-86. https://doi.org/10.1590/1983-40632016v4742790

Srivastava, A.K., Ratnakumar, P., Minhas, P. S., \& Suprasanna, P. (2016). Plant bioregulators for sustainable agriculture: Integrating redox signaling asa possible unifying mechanism. Advances in Agronomy (pp. 237-278). https://doi.org/10.1016/bs.agron.2015.12.002

Veritas $^{\mathrm{TM}}$. (2017). Veritas: Eficiência de cultivos. Retrieved from http://www.plantimpact.com/ /media/ Files/P/PlantImpact/Crops\%20and\%20products/Veritas\%20FAQ\%20ENglish\%20FINAL\%2019102016.pdf

Weatherley, P. E. (1950). Studies in the water relations of the cotton plant. I. The field measurement of water deficit in leaves. New Phytologist, 49, 81-97. https://doi.org/10.1111/j.1469-8137.1950.tb05146.x

\section{Copyrights}

Copyright for this article is retained by the author (s), with first publication rights granted to the journal.

This is an open-access article distributed under the terms and conditions of the Creative Commons Attribution license (http://creativecommons.org/licenses/by/4.0/). 